\title{
Pemanfaatan Kulit Jagung sebagai Bioadsorben untuk Meregenerasi Minyak Goreng Bekas
}

\author{
Umi Fathanah $^{1 *}$, Mirna Rahmah Lubis ${ }^{2}$ \\ ${ }^{1,2}$ Jurusan Teknik Kimia Fakultas Teknik Universitas Syiah Kuala, Banda Aceh \\ *Koresponden email: umifathanah@unsyiah.ac.id
}

Diterima: 5 Januari 2022

Disetujui: 20 Januari 2022

\begin{abstract}
Cooking oil is a food processing medium that is often used by various levels of society for cooking needs. People's habit of using cooking oil repeatedly at high temperatures will cause damage to the oil so that it greatly affects the nutrition and quality of processed foods. For this reason, it is very important to make efforts to regenerate cooking oil that has been used repeatedly with a safer process. Corn husks can be used as a bioadsorbent to regenerate used cooking oil. The purpose of this study was to investigate the effect of adding bioadsorbent from corn husks on the acquisition of moisture content, free fatty acids (FFA), and peroxide number. $200 \mathrm{ml}$ of used cooking oil was contacted with corn husk bioadsorbent with the addition of 1,5 , and 10 grams of bioadsorbent and contact times of 30, 60, and 90 minutes. Furthermore, used cooking oil that has been regenerated was analyzed for moisture content, FFA, and peroxide number. The results showed that 10 grams of bioadsorbent with a contact time of 90 minutes had a moisture content of $0.15 \%$, FFA $0.11 \%$, and a peroxide number of $1.15 \mathrm{meq} / \mathrm{kg}$, which met the cooking oil quality standard (SNI 3741-1995).
\end{abstract}

Keywords: corn husk, moisture content, free fatty acid, peroxide number, used cooking oil

\begin{abstract}
Abstrak
Minyak goreng adalah suatu media pengolahan makanan yang sering digunakan oleh berbagai lapisan masyarakat untuk kebutuhan memasak. Kebiasaan masyarakat menggunakan minyak goreng secara berulang kali pada suhu yang tinggi akan mengakibatkan kerusakan pada minyak sehingga sangat berpengaruh terhadap gizi maupun mutu bahan pangan yang diolah. Untuk itu sangat penting dilakukan upaya untuk meregenerasi minyak goreng yang telah digunakan secara berulang dengan proses yang lebih aman. Kulit jagung dapat digunakan sebagai bioadsorben untuk meregenarasi minyak goreng bekas. Tujuan penelitian ini adalah untuk menginvestigasi pengaruh penambahan bioadsorben dari kulit jagung terhadap perolehan kadar air, asam lemak bebas, serta bilangan peroksida. Minyak goreng bekas sebanyak $200 \mathrm{ml}$ dikontakkan dengan bioadsorben kulit jagung dengan penambahan bioadsorben sebanyak 1, 5, dan 10 gram serta waktu kontak selama 30, 60, dan 90 menit. Selanjutnya minyak goreng bekas yang telah diregenerasi dilakukan analisis terhadap kadar air, asam lemak bebas (ALB) serta bilangan peroksida. Hasilnya menunjukkan bahwa bioadsorben 10 gram bioadsorben dengan waktu pengontakan 90 menit memiliki kadar air sebesar $0,15 \%$, ALB 0,11\%, dan bilangan peroksida $1,15 \mathrm{meq} / \mathrm{kg}$, yang memenuhi standar kualitas minyak goreng (SNI 3741-1995).
\end{abstract}

Kata Kunci: kulit jagung, kadar air, asam lemak bebas, bilangan peroksida, minyak goreng bekas

\section{Pendahuluan}

Masyarakat memerlukan berbagai kebutuhan sandang, pangan dan papan dalam mempertahankan hidupnya. Salah satu bahan kebutuhan pokok yang termasuk dalam kebutuhan pangan, yang biasanya digunakan sebagai media pengolahan makanan adalah minyak goreng. Minyak goreng dapat berperan penting untuk meningkatkan nilai gizi suatu bahan pangan, rasa, aroma, serta daya simpan suatu produk [1]. Dengan semakin meningkatnya jumlah penduduk, tentunya pemenuhan pangan seperti minyak goreng juga akan mengalami kenaikan. Biasanya penggunaan minyak goreng bekas (MGB) di kalangan masyarakat yang termasuk pada tingkatan ekonomi menengah ke atas, hanya digunakan sebanyak tiga kali pemakaian. Namun ada juga kelompok masyarakat, dengan penggunaan minyak goreng dengan intensitas yang lebih sering dalam pemakaiannya, biasanya lebih dari 3 kali pemakaian, sehingga minyak goreng mengalami perubahan warna menjadi coklat bahkan sampai berwarna kehitaman. Padahal penggunaan MGB tersebut sebenarnya tidak layak lagi untuk digunakan kembali [2]. 
Penggunaan MGB sangat membahayakan tubuh serta berpotensi menimbulkan berbagai penyakit penyakit dalam tubuh. Ketika proses penggorengan, maka sebagian minyak akan mengalami reaksi adsorpsi lalu masuk pada bagian luar bahan yang digoreng yang selanjutnya menuju ruang-ruang kosong yang sebelumnya bagian ini terisi air. Produk makanan hasil proses penggorengan biasanya mengandung minyak dengan kisaran 5-40\%. Oleh karena itu jika proses penggorengan menggunakan MGB, maka tentu saja makanan hasil produk gorengan tersebut akan berbahaya bagi kesehatan manusia, disebabkan karena mengonsumsi minyak yang telah rusak. Bahaya yang ditimbulkan antara lain adalah penyakit kanker, terjadinya pengendapan lemak pada pembuluh darah (artherosclerosis) [3] [4].

Kerusakan minyak karena pemanasan yang berulang-ulang, dapat terlihat dari perubahan warna, viskositas yang tinggi, meningkatnya ALB, kenaikan bilangan peroksida serta penurunan bilangan iod [5]. Secara umum MGB mengandung senyawa-senyawa lain seperti senyawa aldehid, senyawa aromatik, polimer dan ALB. Senyawa polar yang terkandung dalam MGB dapat berkisar antara 25 hingga 27\%, yang mengidentifikasikan bahwa kualitas MGB telah menurun, dan berbahaya bagi kesehatan [6]. Selain itu molekul-molekul dalam MGB juga mengalami penguraian, sehingga terjadi penurunan titik asap, yang memicu terjadinya bau tengik. Disamping itu penyimpanan yang terlalu lama juga dapat menyebabkan terbentuknya asam lemak dan gliserol, yang terjadi akibat terpecahnya senyawa trigliserida (TG). Adapun terpecahnya senyawa TG menghasilkan asam lemak dan gliserol dapat dilihat pada Gambar 1 berikut [7]:<smiles>[R]C(=O)OCC(COC([R1])=O)OC([R])=O</smiles>

Gambar 1. Reaksi senyawa trigliserida menjadi asam lemak dan gliserol [7]

ALB juga terbentuk disebabkan karena terjadinya reaksi hidrolisis pada saat pemananasan atau peroses penggorengan. Proses hidrolisis ini memicu terbentuknya kenaikan ALB, gliserol, monogliserol dan diagliserol [8]. Reaksi hidrolisis pada minyak akan semakin cepat terpicu, bila didalam minyak terdapat kandungan air, dalam bahan pangan olahan. ALB yang melebihi ambang batas normal pada makanan olahan menyebabkan meningkatnya inflammation systemic yang dapat dilihat dari kehadiran interleukin serta protein-C reaktif yang dampaknya dapat berakibat pada gagal jantung serta kematian secara mendadak. Selain terjadi peningkatan asam lemak, pemanasan yang berulang akan terbentuk asam lemak trans pada MGB [9]. Oleh sebab itu pemurnian MGB perlu dilakukan sebagai upaya penghematan, tentunya dengan menggunakan metode yang sederhana, mudah dan murah.

Berbagai upaya untuk pengolahan MGB telah dilakukan, salah satunya adalah dengan proses adsorpsi. Adsorpsi dipilih karena mudah dalam pelaksanaannya serta murah. Berbagai bahan yang berasal dari limbah pertanian telah banyak digunakan sebagai adsorben untuk peningkatan kualitas MGB, antara lain menggunakan tandan kosong kelapa sawit [10]; tempurung kelapa [11]; kulit singkong [12]; ampas tebu [13]; dan biji salak [14].

Pada penelitian ini digunakan bioadsorben yang berasal dari limbah pertanian yaitu kulit jagung. Kulit jagung memiliki kandungan selulosa yang tinggi yaitu sebesar 36\% [15], sehingga kulit jagung dapat dimanfaatkan sebagai bioadsorben. Selulosa mengandung beberapa microfibril yang diikat oleh lamellae, sedangkan lamellae tersusun dari beberapa fibril. Selulosa tergolong kedalam polimer linear yang bersifat hidrofilik, dimana satu sama lain saling berikatan membentuk elementrary fibril (photofibril), dengan ukuran lebar, lebar dan tebal masing-masing sebesar 40 A,30 A dan 100 A. Polimer linear yang terdapat pada elementary fibril membentuk susunan paralel, yang terikat melalui ikatan hidrogen yang membentuk struktur kristalin, yang dikelilingi dengan susunan dengan stuktur parakristalin atau amourphous. Adanya stuktur yang menyebabkan selulosa dapat berperan sebagai adsorben [16]. Penelitian ini bertujuan untuk menginvestigasi kemampuan bioadsorben dari kulit jagung terhadap penurunan kadar air, asam lemak bebas (ALB), serta bilangan peroksida pada minyak goreng bekas (MGB). 


\section{Metode Penelitian \\ Alat dan Bahan}

Sejumlah peralatan yang digunakan untuk keperluan penelitian adalah peralatan gelas kimia, hot plate, magnetic stirrer, furnace, dan oven. Adapun bahan yang dipakai adalah sampel MGB, kalium hidroksida $(\mathrm{KOH})$, kulit jagung, alkohol, indikator phenolptalin. Penelitian dilakukan melalui 3 (tiga) tahapan, yaitu (1) preparasi kulit jagung menjadi bioadsorben; (2) regenerasi (proses pemurnian) MGB menggunakan bioadsorben, (3) analisa MGB hasil dari proses pemurnian meliputi kadar air, ALB dan bilangan peroksida.

\section{Prosedur Kerja}

\section{Preparasi kulit jagung menjadi bioadsorben}

Kulit jagung dibersihkan dari kotoran dan dikeringkan di bawah sinar matahari. Selanjutnya dipotong-potong dan dihaluskan menggunakan crusher dan disaring dengan screening ukuran 100 mesh. Kemudian kulit jagung direndam dalam $\mathrm{NaOH}$ dengan konsentrasi 0,25 $\mathrm{N}$ sambil dilakukan pengadukan selama 1 jam. Selanjutnya ditambahkan larutan $\mathrm{HCl}$ 0,25 N untuk penetralan. Setelah tahap penetralan selesai, kemudian disaring dan dilanjutkan dengan pencucian menggunakan akuades. Tahapan terakhir bioadsorben kulit jagung dikeringkan dalam oven diatur pada temperatur $105^{\circ} \mathrm{C}$ selama 4 jam.

\section{Pemurnian Minyak goreng Menggunakan Bioadsorben}

Sampel MGB disiapkan sebanyak $200 \mathrm{ml}$, yang sebelumnya telah dilakukan penyaringan untuk menghilangkan kotoran atau sisa-sisa makanan pada minyak. Selanjutnya dilakukan penambahan bioadsorben sesuai dengan variasi yang ditetapkan (1 gram, 5 gram dan 10 gram), dan dilakukan pengadukan dengan variasi waktu (30 menit, 60 menit serta 90 menit). Kemudian MGB hasil pemurnian disaring dengan kertas saring whatman, dan minyak siap untuk dianalisa.

Analisis Minyak Goreng Bekas (MGB)

Tahap terakhir adalah analisa kualitas MGB yang telah dilakukan pemurnian menggunakan bioadsorben, dengan meninjau beberapa parameter antara lain, analisa kadar air, ALB serta bilangan peroksida. Selanjutnya hasil analisa dari beberapa parameter tersebut, dibandingkan dengan standar mutu kualitas minyak goreng SNI-1995. Adapun prosedur analisa sebagai berikut:

\section{Kadar Air}

Penentuan kadar air menggunakan metode oven terbuka, yaitu sampel dilakukan pengadukan hingga sempurna sebelum dianalisa. Sifat air memiliki kecenderunagn untuk selalu menguap, pengadukan dilakuakn hingga homogen agar terjadi penguapan sempurna. Sampel ditimbang sebanyak 5 gram di dalam cawan, selanjutnya dikeringkan dalam oven, pada suhu $130^{\circ} \mathrm{C}$ dengan waktu 1 jam. Setelah 1 jam sampel dikeluarkan untuk didinginkan dan disimpan dalam desikator. Selanjutnya sampel ditimbang, dan dilakukan pengulangan hingga berat mencapai konstan. Berat air yang konstan, mengidentifikasikan bahwa semua air yang berada dalam minyak telah menguap seluruhnya, sedangkan yang tersisa adalah hanya berat minyak tersebut. Kadar air dapat dihitung menggunakan persamaan 1.

$$
\text { Kadar Air }=\frac{A-B}{A} \times 100 \%
$$

A merupakan massa sampel MGB regenerasi sebelum dimasukkan oven, dan B merupakan massa sampel MGB setelah dioven

Asam Lemak Bebas (ALB)

ALB adalah salah satu parameter yang penting, yang harus dianalisa pada MGB yang telah mengalami kerusakan. Terbentuknya ALB karena trigliserida (minyak) yang terhidrolisis. Oksidasi lebih lanjut akan menyebabkan perubahan rasa yang kurang sedap dan bau yang menyengat pada MGB. Bilangan asam merupakan banyaknya ALB dengan cara menghitung berat molekul suatu asam lemak ataupun campuran dari asam lemak. Penentuan angka asam pada prinsipnya yaitu melarutkan suatu minyak atau lemak dalam suatu pelarut organik, yang selanjutnya dilakukan titrasi menggunakan larutan basa. Angka asam yang besar mengidentifikasikan nilai ALB yang tinggi pula didalam minyak. Keberadaan ALB yang besar dalam minyak, juga akan mengakibatkan perubahan rasa pada minyak sehingga minyak tidak lezat. Penentuan bilangan asam menggunakan persamaan 2 berikut [17]:

$$
\text { Bilangan asam }=\frac{y K O H \times n K O H \times 56,1}{\text { massa sampel }(\text { gram })}
$$


y merupakan banyaknya jumlah $\mathrm{KOH}$ titrasi yang habis terpakai; $\mathrm{n}$ merupakan normalitas $\mathrm{KOH}$, serta 56,1 adalah berat molekul $\mathrm{KOH}$.

\section{Bilangan Peroksida}

Bilangan peroksida adalah angka yang paling penting untuk menentukan tingkat kerusakan pada minyak atau lemak. Peroksida dapat terbentuk dari asam lemak jenuh yang mengikat unsur oksigen pada ikatan rangkapnya. Bilangan peroksida dapat dihitung menggunakan metode iodometri. Penentuan bilangan peroksida ini dihitung berdasarkan banyaknya iodin yang dilepaskan, setelah minyak ditambahkan senyawa kalium iodida (KI). Selanjutnya minyak direaksikan dengan larutan KI menggunakan pelarut asam asetat dan kloroform dengan rasio 2:1, dimana iodin yang dihasilkan ditentukan dengan menggunakan titrasi thiosulfat. Bilangan peroksida ini akan menguraikan ikatan aldehid dan karbonil yang terbentuk pada proses pemanasan pada suhu yang tinggi. Bilangan peroksida dapat dihitung menggunakan persamaan 3 berikut [17]:

$$
\text { Bilangan peroksida }=\frac{(t s-t b) \times n \cdot N a 2 S 203 \times 1000}{\text { massa sampel }(\text { gram })}
$$

ts merupakan banyaknya volume $\mathrm{Na}_{2} \mathrm{~S}_{2} \mathrm{O}_{3}$ titrasi yang habis terpakai; tb merupakan volume $\mathrm{Na}_{2} \mathrm{~S}_{2} \mathrm{O}_{3}$ titrasi blangko, dan $\mathrm{n}$. $\mathrm{Na}_{2} \mathrm{~S}_{2} \mathrm{O}_{3}$ adalah konsentrasi (normalitas) $\mathrm{Na}_{2} \mathrm{~S}_{2} \mathrm{O}_{3}$

\section{Hasil dan Pembahasan}

\section{Kadar Air}

Minyak goreng yang didalamnya terdapat kandungan air, dapat menyebabkan reaksi hidrolisa, yang mengakibatkan terpecahnya trigliserida minyak membentuk gliserol dan ALB. Reaksi hidrolisa ini dibantu oleh beberapa parameter seperti adanya uap air, kandungan asam, alkali, adanya enzim serta suhu yang tinggi. Reaksi yang terjadi lebih lanjut akan menghasilkan produk aldehid dan keton, dimana kedua senyawa ini mengidentifikasikan bau tidak sedap seperti bau tengik (rancidity) pada minyak. Disamping itu kandungan air yang tinggi dalam minyak dapat mengakibatkan kontaminasi bakteri yang dapat memicu reaksi hidrolisis pada molekul lemak. Keberadaan air dalam minyak biasanya dalam bentuk koloid, dimana air akan distabilkan oleh adanya protein dalam minyak. Oleh sebab itu keberadaan air halam minyak harus seminim mungkin untuk menjaga kualitas minyak goreng [18].

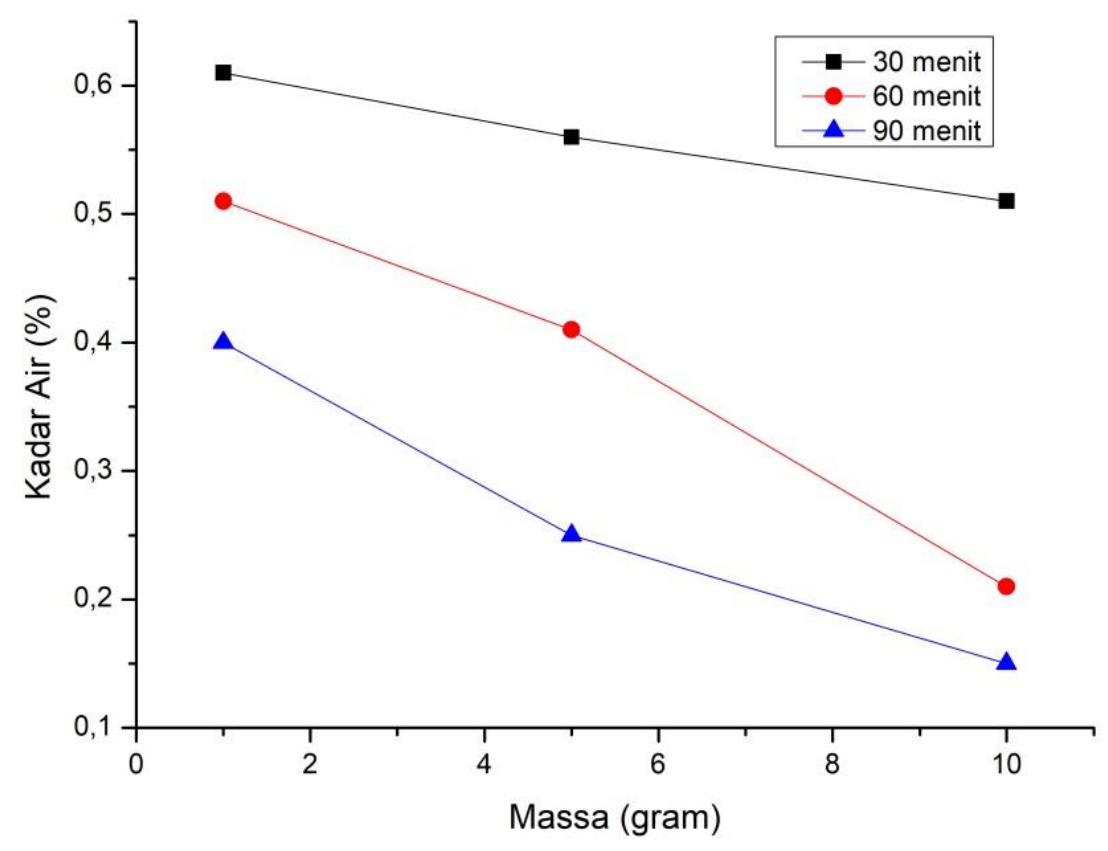

Gambar 2. Hubungan massa bioadsorben terhadap nilai kadar air pada berbagai waktu kontak Sumber : Hasil pengujian penelitian (2021) 
Gambar 2, memperlihatkan grafik hubungan massa bioadsorben terhadap kadar air pada berbagai waktu kontak. Pada Gambar 2, terlihat bahwa dengan semakin meningkatnya bioadsorben yang ditambah, kadar air yang dihasilkan juga makin rendah. Kadar air minyak goreng hasil regenerasi berkisar pada 0,62$0,2 \%$. Berkurangnya kadar air karna adanya reaksi adsorpsi fisik pada molekul hidroksil $(-\mathrm{OH})$ yang diserap oleh bioadsorben kulit jagung. Hal ini terjadi karena adanya beda energi potensial antara adsorben dan zat yang diserap. Interaksi yang tinggi antara bioadsorben dengan molekul $-\mathrm{OH}$, akan menyebabkan semakin besar pula molekul hidroksil (-OH) yang diserap dalam pori-pori bioadsorben [18]. Pada gambar juga terlihat bahwa semakin lama waktu pengontakan, maka semakin rendah nilai kadar air minyak. Hal ini terjadi karena semakin lama proses adsorpsi yang terjadi, maka waktu kontak antara bioadsorben juga semakin besar, sehingga penyerapan yang terjadi juga semakin optimal. Kadar air terendah diperoleh sebesar $0,15 \%$ yaitu pada penambahan bioadsorben 10 gram dengan waktu kontak 90 menit. Nilai kadar air ini masih berada dalam standart yang ditetapkan SNI 3741-1995, yang mensyaratkan kandungan air yang diizinkan maksimal $0,3 \%$.

\section{Asam Lemak Bebas (ALB)}

Sifat penting yang lain dalam kandungan minyak goreng adalah asam lemak bebas (ALB), yang biasa digunakan untuk mengontrol kualitas minyak. Tingginya ALB sangat berpengaruh terhadap cita rasa dan bau minyak sehingga mutu minyak menjadi rendah. ALB akan mempengaruhi sifat fisika dan kimia serta kestabilan minyak. Gambar 2 memperlihatkan hubungan penambahan massa bioadsorben terhadap ALB pada berbagai variasi waktu kontak.

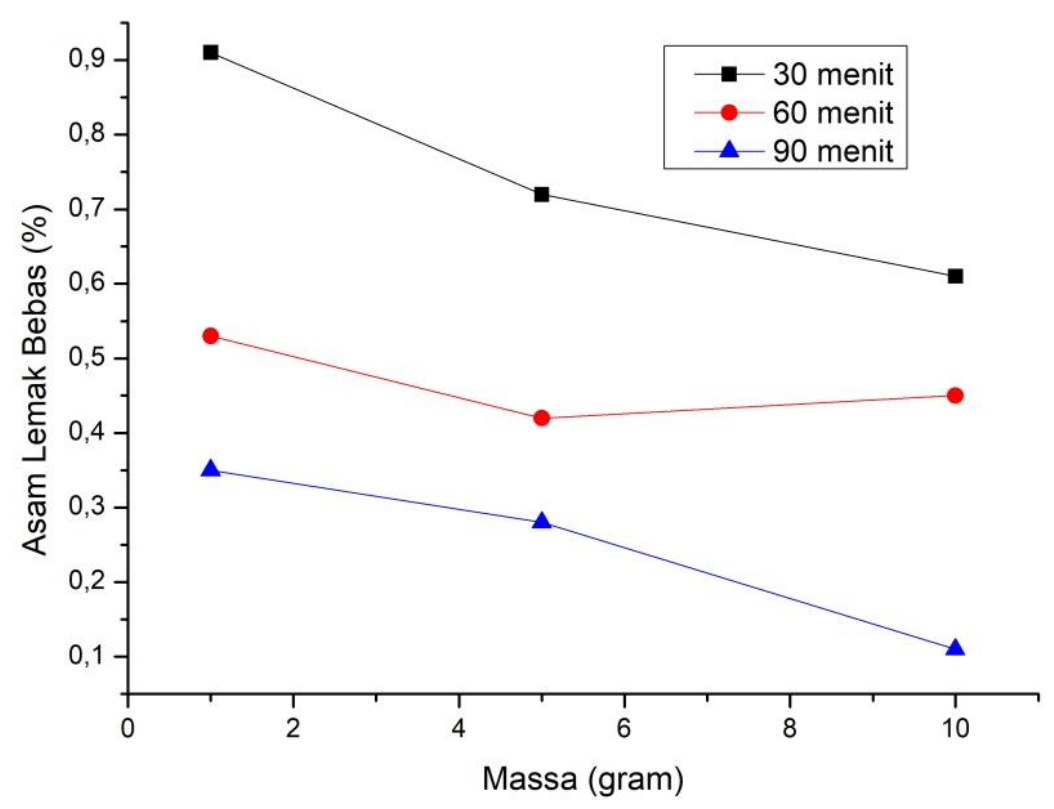

Gambar 3. Hubungan massa bioadsorben terhadap bilangan asam lemak bebas (ALB) pada berbagai variasi waktu kontak

Sumber: Hasil pengujian penelitian (2021)

Berdasarkan Gambar 3, terlihat bahwa semakin banyak bioadsorben yang ditambahkan, maka kadar ALB juga mengalami penurunan. Kadar ALB juga berkurang dengan semakin lamanya waktu kontak. Pada penelitian ini nilai kadar ALB yang diperoleh berkisar 0,9-0,11\%. Nilai ALB mengalami penurunan setelah proses adsorbsi menggunakan bioadsorben dari kulit jagung. Dalam Kulit jagung memiliki selulosa, dimana selulosa ini terdapat gugus hidroksil $(-\mathrm{OH})$ yang memiliki sifat elektronegatif (basa) dan polar, yang memiliki kemampuan bereaksi dengan gugus karboksilat (-COOH) pada ALB yang besifat elektropositif (asam) dan polar [1]. Kemampuan interaksi yang terjadi ini, mengakibatkan ALB mengalami penurunan. Kadar ALB terbaik diperoleh pada penambahan bioadsorben sebanyak 10 gram, dengan waktu kontak selama 90 menit yaitu sebesar $0,11 \%$. Nilai ALB yang diperoleh masih dalam range standar SNI minyak goreng yaitu maksimum $0,2 \%$. 


\section{Bilangan Peroksida}

Salah satu parameter penting untuk mengidentifikasi derajat kerusakan minyak yaitu bilangan peroksida. Asam lemak tidak jenuh dapat teroksidasi pada ikatan rangkapnya membentuk peroksida. Terbentuknya peroksida menunjukkan proses oksidasi telah terjadi pada minyak. Bilangan peroksida yang tinggi pada minyak, menunjukkan bahwa tingkat kerusakan minyak juga semakin besar. Semakin tinggi bilangan peroksida, maka semakin luas oksidasi yang terjadi pada minyak, yang berarti bahwa semakin berlanjut kerusakan pada minyak yang ditandai bau tengik pada minyak semakin menyengat. Adapun angka peroksida dalam minyak dapat ditentukan secara iodometri [19]. Melalui metode iodometri peroksida yang terbentuk dalam minyak akan direduksi.

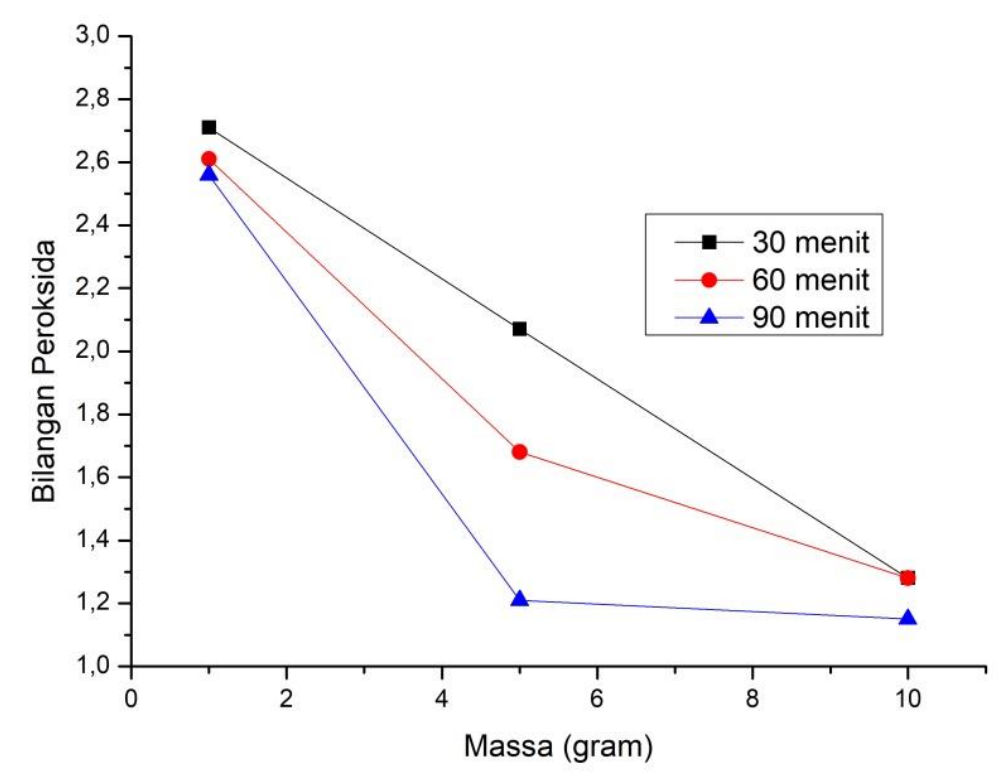

Gambar 4. Hubungan massa bioadsorben terhadap bilangan peroksida pada berbagai variasi waktu kontak.

Sumber: Hasil pengujian penelitian (2021)

Berdasarkan Gambar 4, terlihat bahwa semakin banyak massa bioadsorben yang ditambahkan, terlihat bahwa bilangan peroksida juga semakin berkurang. Demikian juga dengan semakin lama waktu kontak yang terjadi, terlihat kecenderungan penurunan bilangan peroksida pada minyak. Pada penelitian ini, diperoleh bilangan peroksida dalam kisaran 2,73-1,15.

Kulit jagung memiliki selulosa yang didalamnya banyak kandungan gugus hidroksil (-OH) yang bersifat polar. Gugus hidroksil (-OH) ini mempunyai afinitas yang tinggi terhadap zat terlarut yang memiliki sifat polar juga. Sifat kepolaran yang tinggi dari senyawa peroksida dalam minyak, memberi kemudahan bagi bioadsorben untuk menyerap senyawa peroksida dalam minyak. Dapat dinyatakan bahwa dengan semakin banyak adsorben yang ditambahkan, maka semakin banyak peroksida yang diserap dalam minyak. Demikian juga dengan semakin lama waktu kontak, maka kontak yang terjadi antara adsorben (kulit jagung) dengan adsorbat (senyawa peroksida) akan semakin baik, sehingga bilangan peroksida akan semakin berkurang. Penurunan bilangan peroksida yang dihasilkan dalam penelitian ini masih memenuhi standar SNI adalah pada penambahan bioadsorben sebanyak 5 dengan waktu kontak 60 menit yaitu 1,28 $\mathrm{meq} / \mathrm{kg}$ serta penambahan bioadsorben sebanyak 10 gram dengan waktu kontak 90 menit dengan nilai 1,15 $\mathrm{meq} / \mathrm{kg}$.

\section{Kesimpulan}

Penelitian tentang pemanfaatan kulit jagung sebagai bioadsorben untuk meregenerasi minyak goring bekas (MGB) telah dilakukan. Peningkatan MGB yang telah dimurnikan menggunakan bioadsorben dapat dilihat dari penurunan kadar air, senyawa asam lemak bebas (ALB), serta bilangan peroksida. Bioadsorben kulit jagung terbaik diperoleh pada penambahan massa bioadsorben sebanyak 10 gram dengan waktu kontak selama 90 menit, yang menghasilkan kualitas minyak goreng dengan kadar air sebesar $0,15 \%$, ALB sebesar $0,11 \%$, serta bilangan peroksida sebesar $1,15 \mathrm{meq} / \mathrm{kg}$. Nilai yang diperoleh pada semua parameter yang diuji telah memenuhi syarat SNI 3741-1995 standar mutu minyak goreng. 


\section{Daftar Pustaka}

[1] S. Rahayu, Lucia Hermawati, Puranvita, "Pengaruh Suhu dan Waktu Adsorbsi Terhadap Sifat Kimia Fisika Minyak Goreng Bekas Hasil Pemurnian Menggunakan Adsorben Ampas Pati Aren dan Bentonit," Momentum, vol. 10, no. 2, pp. 35-41, 2014.

[2] Juherah Juherah and I. I. Khiki Purnawati Kasim, "Pemanfaatan Arang Bonggol Jagung Sebagai Adsorben Minyak Goreng Bekas (Jelantah) (Eksperimen)," J. Sulolipu Media Komun. Sivitas Akad. dan Masy., vol. 21, no. 2, pp. 251-257, 2021.

[3] N. Fanani dan E. Ningsih, "Analisis Kualitas minyak Goreng Habis Pakai yang Digunakan oleh Pedagang Penyetan di Daerah Rungkut Surabaya Ditinjau dari Kadar Air dan Kadar Asam Lemak Bebas,” J. IPTEK Media Komun. Teknol., vol. 22, pp. 59-66, 2018, doi: 10.31284/j.iptek.2018.v22i2.

[4] L. Nurdianni, Indah, Suwadiyono, Suwardiyono, Kurniasari, "Pengaruh Ukuran Partikel dan Waktu Perendaman Ampas Tebu pada Peningkatan Kualitas Minyak Jelantah,” J. Inov. Tek. Kmia, vol. 6, no. 1, pp. 28-36, 2021.

[5] F. C. Hidayati and I. Yulianti, "Pemurnian Minyak Goreng Bekas Pakai ( Jelantah ) dengan Menggunakan Arang Bonggol Jagung,” J. Ilmu Pendidik. Fis., vol. 1, no. 2, pp. 67-70, 2016.

[6] D. Nasrun and T. Samangun, "Pemurnian minyak jelantah menggunakan arang aktif dari sekam padi," eUREKA J. Penelit. Tek. Sipil dan Tek. Kim., vol. 1, no. 2, 2017.

[7] S. W. S. Rahadiningrum, Mahreni, R. Reningtyas, and R. Hendri Gusaptono, "Biopelumas dari Minyak Nabati (Review)," Eksergi, vol. XIII, no. 2, pp. 14-19, 2016.

[8] C. C. Osawa and L. A. G. Gonçalves, "Changes in Breaded Chicken and Oil Degradation During Discontinuous Frying with Cottonseed Oil," Food Sci. Technol., vol. 32, no. 4, pp. 692-700, 2012, doi: 10.1590/s0101-20612012005000098.

[9] H. Y. Fan, M. S. Sharifudin, M. Hasmadi, and H. M. Chew, "Frying Stability of Rice Bran Oil and Palm Olein," Int. Food Res. J., vol. 20, no. 1, pp. 403-407, 2013.

[10] D. H. Adam, "Kemampuan Tandan Kosong Kelapa Sawit Sebagai Adsorben Untuk Meregenerasi Minyak Jelantah," Edu Sci., vol. 4, no. 1, pp. 8-11, 2017.

[11] M. Pakiding, Lewi Meichal, Ni Ketut, Sumarni, "Aktifasi Arang Tempurung Kelapa dengan ZnC12 dan Aplikasinya dalam Pengolahan Minyak Jelantah," J. Nat. Sci., vol. 3, no. 1, pp. 47-54, 2014.

[12] A. Zunifer and D. F. Ayu, "Particle Size and Contact Time of Activated Carbon From Cassava Skin on Quality of Used Cooking Oil," SAGU J. Agric. Sci. Technol., vol. 19, no. 2, pp. 27-38, 2020.

[13] Z. Octarya and A. Fernando, "Peningkatan Kualitas Minyak Goreng Bekas dengan Menggunakan Adsorben Arang Aktif dari Ampas Tebu yang Diaktivasi dengan NaCl," J. Phot., vol. 6, no. 2, pp. 139-148, 2016.

[14] S. Fadlia, Ihwan, Anam, "Mutu Minyak Jelantah dengan Adsorben Biji Salak ( Salacca zalacca ( Gaertn . Voss ) Menggunakan Parameter Bilangan Peroksida dan Asam Lemak Bebas," J. Farm. Galen. (Galenika J. Pharmacy), vol. 5, no. 2, pp. 124-131, 2019, doi: 10.22487/j24428744.2019.v5.i2.10070.

[15] N. A. Oktaffi Arinna Manasikana, Andhika Mayasari, "Pemanfaatan Limbah Kulit Jagung dan Ampas Tebu Sebagai Kertas," J. Zarah, vol. 7, no. 2, pp. 79-85, 2019.

[16] Y. Yustinah, "Pengaruh Massa Bioadsorben dari Klobot Jagung pada Proses Adsorbsi Minyak Goreng Besas," Semin. Nasioanal Kim. Terap. Indones., vol. 4, pp. 13-16, 2013.

[17] F. dan N. H. Fitriani, "Pemurnian Minyak Goreng Bekas Menggunakan Adsorben Biji Alpukat Teraktivasi," J. Pendidik. Mat. dan IPA, vol. 9, no. 2, pp. 65-75, 2018, doi: 10.26418/jpmipa.v9i2.26770.

[18] S. Oko, M. Mustafa, K. Andri, and M. Nur Afni, "Purification of Waste Cooking Oil Adsorption Method Using Active Charcoal from Iron wood Sawdust (Eusideroxylon zwageri)," J. Ris. Teknol. Ind., vol. 14, no. 2, pp. 124-132, 2020.

[19] A. S. Suroso, "Kualitas Minyak Goreng Habis Pakai Ditinjau dari Bilangan Peroksida, Bilangan Asam dan Kadar Air," J. Kefarmasian Indones., vol. 3, no. 2, p. 2013, 2013. 